\title{
A spirochete-like bacteria observed in Gram-stained vaginal smears.
}

\section{Letter to the Editor}

Francisco Hernández-Chavarría ${ }^{1}$, Victoria Cháves ${ }^{2}$.

${ }^{1}$ Unidad de Microscopia Electrónica, Universidad de Costa Rica, San José, Costa Rica, ${ }^{2}$ Calderón Guardia Hospital, San José, Costa Rica.

Bacterial vaginosis is a common and often underdiagnosed condition. It is the most frequent cause of vaginal discharge, affecting 8 to $15 \%$ of women (1), and it is associated with alterations of the vaginal microbial ecosystem, loss of commensal lactobacilli and increased $\mathrm{pH}$, leading to polymicrobial colonization and malodorous discharge. While a normal vaginal Gram smear shows a predominance of Gram positive bacilli, in bacterial vaginosis there is an overgrowth of aerobic and anaerobic Gram negative rods, including Gardnerella, Prevotella, Bacteroides, and Mobiluncus (1-3).

We report here the finding of a previously unreported large spirochete-like bacterium in Gram smears of vaginal secretions from two patients with bacterial vaginosis.

The first case was a 28 year-old-woman who presented vaginal discharge. A Gram-stained smear from a vaginal swab showed predominance of Gram negative small bacilli and curved Gram negative bacteria and in addition abundant large spirochete-like bacteria. The nurse taking the sample reported the presence of a tampon and the patient confirmed it had remained for at least 10 days in the vagina.

The second case was a 8 year-old-girl with a vaginal secretion and discomfort. The attending pediatrician took a sample of the vaginal secretions and also observed some Enterobius vermicularis in the anal region. A Gram-stain of the vaginal secretion smear showed the characteristic vaginal f1ora of bacterial vaginosis and some large spirochete-like agents.

The adult woman maintained a tampon for at least 10 days inside her vagina, and poor hygienic habits may have caused fecal contamination. In regards to the other patient, it must be remembered that enterobiasis can cause vulvovaginitis in children.

Almost $25 \%$ of the cases are associated with anal pruritus (4), and this may have caused the child to scratch and draw fecal material towards her vagina. Thus, the possibility exists that in both cases fecal bacteria, among them the large spirochetelike agent we observed, may have colonized the

Corresponding address: Dr. Francisco Henández-Chavarría, Unidad de Microscopia Electrónica, Universidad de Costa Rica, San José, Costa Rica. E-mail: hchavarr@cariari.ucr.ac.cr 


\section{F Hernández-Chavarría, V Cháves.}

vagina.

Spirillar bacteria have been previously reported in the colon mucosal surface or in feces from patients with diarrhea (5), but those agents have been visualized only under dark field or phase contrast microscopy, since they were too thin to be observed using the brightness light microscope (resolution limit usually around $0.22 \mu \mathrm{m}$ ). In constrast, our observation of the spirochete-like bacteria was made in Gram stained smears; nevertheless was anecdotal and for that reason isolation was not attempted. The original Gram stained smears were covered with $c a .10 \mathrm{~nm}$ of gold-palladium, in an ion sputter, Eiko IB-3), and observed under a scanning electron microscopy (SEM, Hitachi N-2360), we calculate the thickness of the spirochete-like bacteria to be 0.27 $\mu \mathrm{m}$ (figure 1).

Bacterial vaginosis is associated with alterations of the vaginal ecosystem that promote the establishment of abnormal flora, including anaerobes rods; to our knowledge, this is the first time that spirochete-like bacteria have been observed in Gram stained of vaginal smears. Both patients were treated with oral metronidazole

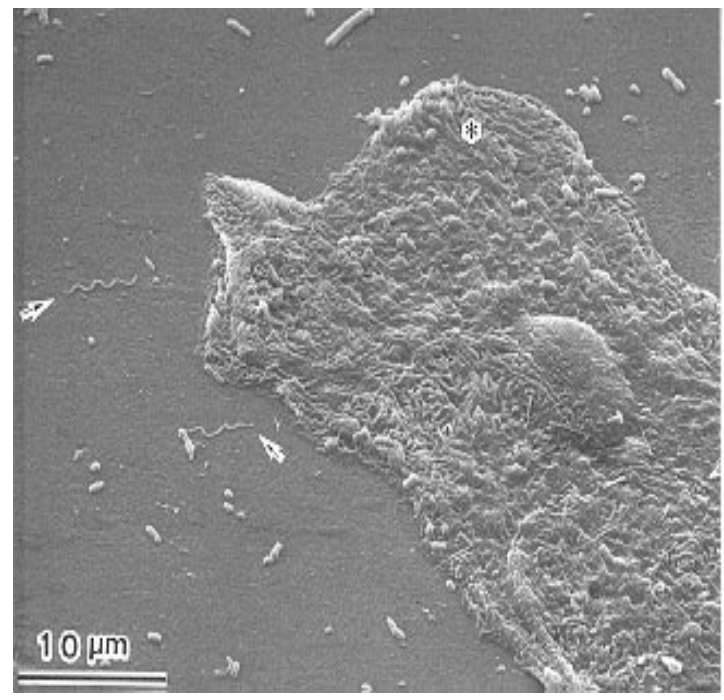

Figure 1.- Scaning electron microscopy (SEM) image of a Gram stained smear from the vaginal secretion of patient one (the glass slide was ion sputtered with $10 \mathrm{~nm}$ of goldpalladium to be observed under SEM). Epithelial cell with short rods attached (asterisk) and in the background there are some Spirochete-like agents (arrows).

Revista Biomédica showing a good clinical response, with disappearance of those bacteria and their manifestations associated with bacterial vaginosis.

Key words: Bacterial vaginosis, spirochetes, Gram smears, scanning electron microscopy.

\section{REFERENCES.}

1.- Spiegel, C. A. The genus Mobiluncus. In A. Balow, H. G. Trüer, M. Dworkin, W. Harder, K. H. Scheeifer (ed.), Prokaryotes. 2nd. Ed. New York: Springer Verlag; 1992. p. 906-917.

2.- Spiegel CA, Amsel R, Holmes KK. Diagnosis of bacterial vaginosis by direct Gram stain of vaginal fluid. $\mathrm{J}$ Clin Microbiol 1983; 18:170-7.

3.- Nugent RP, Krohn MA, Hillier SL. Reliability of diagnosing of bacterial vaginosis is improved by a standardized method of Gram stain interpretation. J Clin Microbiol 1991; 29:297-301.

4. Pawloski ZS. Enterobiasis. In Warren K S, Mahmould AAF ed., Tropical and Geographical Medicine. New York: MacCraw Hill; 1990. p. 404-7.

5.- Malnick H, Williams K, Phil-Ebosie J, Levy AS. Description of a medium for islating Anaerobiospirillum spp., a possible cause of zoonotic desease, from diarrheal feces and blood of humans and use of the medium in a survey of human, canine, and feline feces. J Clin Microbiol 1992; 28:1380-4. 